\title{
Correction to: Assessment of Neurotoxicity Following Single and Co-exposure of Cadmium and Mercury in Adult Zebrafish: Behavior Alterations, Oxidative Stress, Gene Expression, and Histological Impairment in Brain
}

\author{
Utsav N. Patel • Urvesh D. Patel $\mathbb{D}^{\circ}$ \\ Aniket V. Khadayata $\cdot$ Rahul K. Vaja $\cdot$ \\ Harshad B. Patel · Chirag M. Modi
}

Published online: 23 February 2022

(C) Springer Nature Switzerland AG 2022

Correction to: Water Air Soil Pollut (2021) 232: 340

https://doi.org/10.1007/s11270-021-05274-1

The original publication of this article unfortunately contained an error in graphical abstract.

The error has occurred in the direction of arrows showing the MDA level. The corrected graphical abstract is shown below.

The original article can be found online at https://doi.org/ 10.1007/s11270-021-05274-1.

U. N. Patel · U. D. Patel $(\bowtie) \cdot$ A. V. Khadayata .

R. K. Vaja $\cdot$ H. B. Patel · C. M. Modi

Department of Veterinary Pharmacology and Toxicology,

College of Veterinary Science and Animal Husbandry,

Junagadh Agricultural University, Junagadh, India

e-mail: urvesh1981@yahoo.com 


\section{Adult Female Zebrafish}

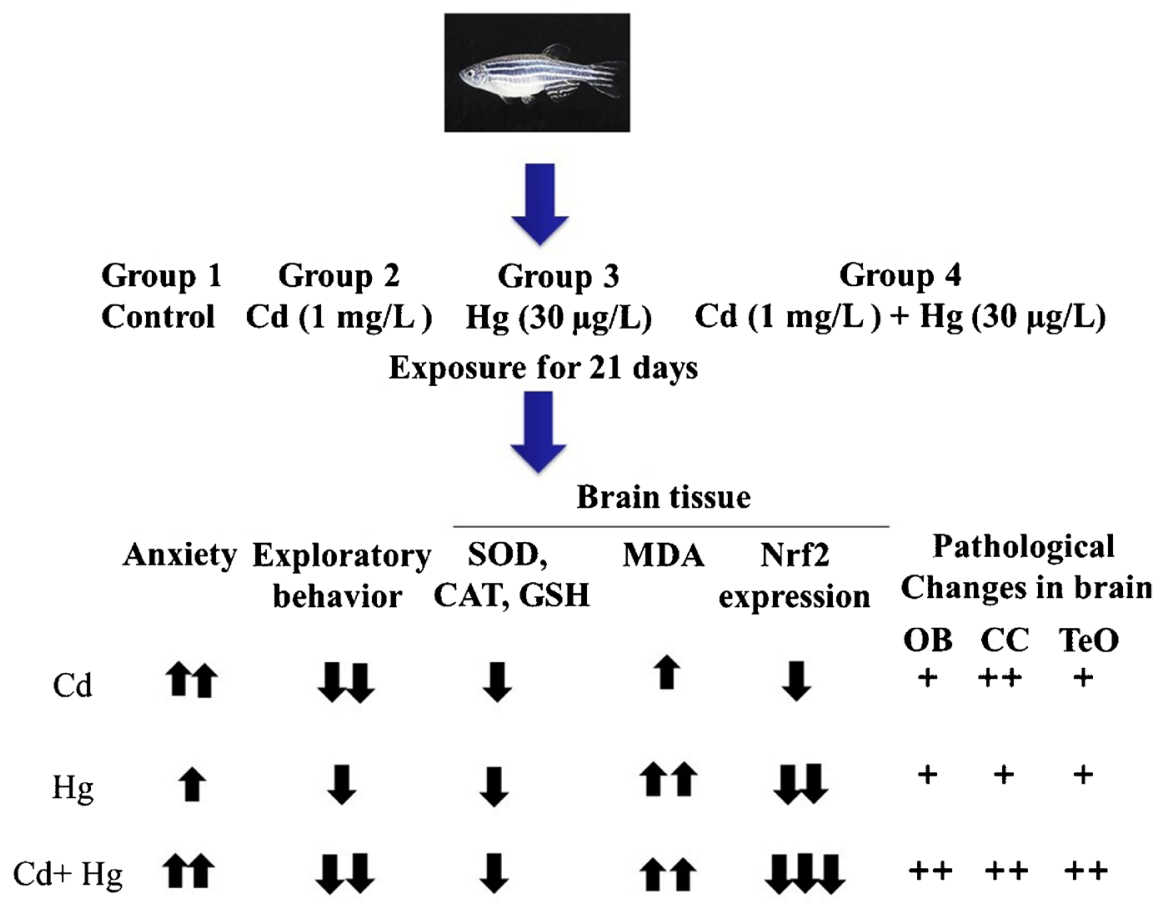

OB: Optic bulb, CC: Corpus cerebelli, TeO: Tectum opticum

Publisher's Note Springer Nature remains neutral with regard to jurisdictional claims in published maps and institutional affiliations. 